\title{
Postwar American Experimental Film and Queer Psychogeography
}

\section{Juan Antonio Suárez \\ University of Murcia \\ Juan Francisco Belmonte-Ávila}

Complutense University of Madrid

\begin{abstract}
This essay reads queer American experimental film of the 1940s and 1950s-by Kenneth Anger, Willard Maas, Gregory Markopoulos, and Curtis Harrington, among others - as a form of queer psychogeography: a style of urban dwelling and transit that originated with French surrealism in the late 1920s and was subsequently theorized by Lettrists and Situationists in the 1950s. Psychogeography consisted in drifting through the city in search of evocative or destabilizing spots, which, for postwar American experimental filmmakers, were locations latent with (queer) sexual possibility. This approach allows us to re-interpret these films from an unprecedented perspective. So far conceptualized as cinematic renderings of trances and dreams triggered by the search for sexual identity, the present article shows that this body of work registers as well a material practice consisting in the covert sexualisation of urban space; this practice arises from the attempt of postwar queer subcultures to escape regulation and surveillance during repressive times.
\end{abstract}

Keywords: experimental film, postwar United States, surrealism, queer culture, urban studies, psychogeography, Kenneth Anger, Gregory Markopoulos, Willard Maas.

\section{Queer (American) Surrealism}

Despite André Breton's homophobic pronouncements, the sexuality of surrealism was far from fixed. The dialogues on sexuality held intermittently during the high years of the movement, gathered in José Pierre's Investigat- 
ing Sex, ${ }^{1}$ show that almost everyone in Breton's group had fairly fluid views of gender identity, sexual fantasy, and desire. Outside these dialogues, much in surrealist life and art points to a libidinal mobility that we now call "queer." Already the first surrealist manifesto demanded that "man" (sic) kept "the body of his desires, daily more formidable, in a state of anarchy." The subsequent collective statement "Hands Off Love" extolled "love sudden and immediate, before all else the great irresistible summons," and defended Charlie Chaplin, accused of "deviance" by his wife at the time during their acrimonious divorce. ${ }^{3}$ For the surrealists, "love" and anarchic desire were not expressed through a normative heterosexual register. Evidence of the movement's expanded eroticism includes Federico García Lorca's homoerotic "Ode to Walt Whitman" (1930); passages in Aragon's Le Paysan de Paris (1926) extoling the ambiguous sexuality of the public baths; much of poet René Crevel's writing (and life); photographs and artworks by Man Ray, which, according to Dickran Tashjian blend paranoia, aggression and homoerotic attraction; ${ }^{4}$ and Duchamp's occasional crossdressing. Further examples include the transgender imaginary of photographers Claude Cahun and Pierre Molinier and the androgynous characters in Dali and Buñuel's Un Chien andalou -Pierre Batcheff in maid's regalia and Fano Messan in a men's suit and tie poking a severed hand with a cane in the middle of the street. Breton himself dressed up as a nun for a picture by Man Ray and was transgendered by Duchamp, who mischievously pasted his face onto the Statue of Liberty in his design for the cover of Young Cherry Trees Secured Against Hares (1946), the first English-language edition of Breton's poems.

American surrealism would further testify to the movement's sexual mobility. Far from the controlling authority of Breton and oblivious to the personal rivalries that prompted tumultuous denunciations and excommunications across the Atlantic, surrealism in the United States became more flexible and less doctrinaire than its French counterpart. In an authorita-

1 José Pierre, ed. Investigating Sex: Surrealist Research, 1928-1932, trans. Malcolm Imrie (New York: Verso, 1988).

2 André Breton, "Manifesto of Surrealism" (1924), Manifestoes of Surrealism, trans. R. Seaver and H. Lane (Ann Arbor: University of Michigan Press, 1969), 18.

3 The Surrealist group, "Hands off Love," rpt. in The Shadow and Its Shadow: Surrealist Writings on the Cinema, Paul Hammond, ed. (London: British Film Institute, 1978), 173-180.

4 Dickran Tashjian, A Boatload of Madmen: Surrealism and the American Avant-Garde, 1920-1950 (London: Thames and Hudson, 1995), 105-06. 
tive study, Dickran Tashjian has claimed that US surrealism was defanged and defused..$^{5}$ Quickly embraced by established museums, art galleries, the fashion industry, and Hollywood, it was turned from an anti-aesthetic -a blueprint for the upheaval of everyday life -into an aesthetic, that is, into collectible art and a style that artists could use selectively without committing wholesale to its programme. We could add that it was depoliticized but also further queered. Or rather, that it exchanged one style of politics for another. It ballasted traditional class and state politics, embodied in the French surrealists' attempts to establish meaningful relationships with the left. But at the same time, it took on what was still then an inchoate politics of the body and sexuality, and became a vehicle for the expression of unconventional - homoerotic - desire and affect. Such mutations in American surrealism have usually been interpreted as the watering down or misunderstanding of the movement's original goals. ${ }^{6}$ Yet David Lomas has insightfully pointed out that rather than dilute the movement they opened it up to "unforeseen emancipatory agendas." In fact, Lomas continues, "consideration of the issue of sexuality causes us to question the subordinate relation of [surrealist] periphery to center." It may have been on alien shores (the United States, among other places) that the sexual anarchy of surrealism became more fully realized than it had been at the source, or, what it's the same, that its intrinsic queerness came more strongly to the fore.

From the start, American surrealism was quickly adopted by artists who did not conform to the heterosexual norm. The first surrealist show in the United States, "The Newer Super-Realism," opened at the Wadsworth Atheneum in November of 1931, curated by Arthur Everett - "Chick" - Austin, the Atheneum's director, and by gallerist Julien Levy. Renamed "Surrealism," it moved to Levy's gallery in New York in February of 1932. The brochure for the New York leg of the show featured a montage by photographer George Platt Lynes titled "As a Wife Has a Cow," inspired by Gertrude Stein's crypto-lesbian short story of the same title. ${ }^{8}$ Before becoming one of the main fashion and dance photographers in 1930s New York, Lynes

5 Tashjian, Boatload of Madmen, 1-3 and ff.

6 David Lomas, Narcissus Reflected: The Myth of Narcissus in Surrealist and Contemporary Art (London: Reaktion Books, 2011), 77 and ff.

7 Lomas, Narcissus Reflected, 77.

8 The story is anthologized in Terry Castle, ed. The Literature of Lesbianism: A Historical Anthology from Ariosto to Stonewall (New York: Columbia University Press, 1993). 
had spent time in France, where he had been close to René Crevel, his lover for a time, as well as to Jean Cocteau, and Gertrude Stein. Aside from his commercial assignments for Harper's Bazaar and for the New York City Ballet, Lynes's work was devoted to the male nude, frequently presented in oneiric settings. In 1936, his photomontage The Sleepwalker was included in Alfred Barr's MoMA exhibition, "Fantastic Art, Dada, and Surrealism," which confirmed his connection with the movement.9

During the 1940s, among the main promoters of surrealism in the United States were Charles Henri Ford and Parker Tyler. They co-edited the magazine View: Through the Eyes of Poets (1940-1947), which was, along with $V V V$, the main English-speaking showcase for the French group during their New York exile. Years before, they had jointly authored The Young and Evil (1933), an experimental novel about the sexual romps and intellectual adventures of a number of queer young bohemians in Greenwich Village. Neither Ford nor Tyler were unqualified surrealists. They were receptive to the movement's iconoclasm and to surrealism's openness towards desire and sexuality, but were also too invested in literary craft and aesthetic values to accept Breton's anti-aesthetic stance. And, as gay men, they objected to Breton's homophobia. After meeting Breton for the first time in Paris in 1932, Ford reported to Tyler: "He is revolted by obvious Lesbians as well as 'fairies' like we used to be ... which does not obviate his looking like a woman in the first place without wearing his hair long in the $2^{\text {nd }}$." And he went on to remark Breton's uncanny resemblance to Oscar Wilde. ${ }^{10}$

On the margins of official surrealism were painters Paul Cadmus and Jared French, whose work had some affinities with the movement. They had met at the Art Students' League of New York in 1926, became involved with each other, and resided in Europe together in the early 1930s before returning to New York, where they were based most of their lives. Cadmus and French were included in the MoMA exhibition "Realists and Magic Realists" (1943), which showcased, in Alfred Barr's words, painting “of sharp

9 Good overviews of George Platt Lynes's career are James Crump, "Photography as Agency: George Platt Lynes and the Avant-Garde" and James Crump, "Iconography of Desire: George Platt Lynes and Gay Male Visual Culture in Postwar New York," George Platt Lynes: Photographs from the Kinsey Institute Collection, introduction by Bruce Weber; preface by June M. Reinisch; essays by James Crump (Boston: Little Brown, 1993), 137-156. On Lynes's dance photography, see Jonathan Weinberg, "Substitute and Consolation: The Ballet Photographs of George Platt Lynes," Dance for a City: Fifty Years of the New York City Ballet, Lynn Garafola with Eric Fornes, eds. (Columbia University Press, 1999), 129-151.

10 Cited in Tashjian, A Boatload of Madmen, 170-171. 
focus and precise representation, whether the subject has been observed in the outer world - realism - or contrived by the imagination - magic realism." 11 Magic realists such as Peter Blume, Louis Guglielmi, Ivan Albright -championed by View - or Jared French, were occasionally categorized as surrealists, even if some rejected the affiliation. Cadmus's painting, for its part, is best described as American-scene realism with a sharp eye for the grotesque. Cadmus and French's surrealist affinities are most evident in the photographs that they both made with French's wife Margaret under the collective name Pajama between the late-1930s and the mid-1950s on the beaches of Fire Island. ${ }^{12}$ The photographs show human figures - usually themselves and their friends - often scantily clad or wrapped in white flowing sheets in settings reminiscent of Tanguy's or Dali's landscapes. Pajama's images are markedly homoerotic; their formal qualities and mythological resonances do not entirely sublimate the immediacy and physicality of the half-naked male bodies that populate them.

In addition to photography, painting and literature, experimental film was an important field for the unfolding of a queer American surrealism, especially during the 1940s and 1950s. Among the best-known filmmakers in this trend are Maya Deren, Kenneth Anger, Gregory Markopoulos, James Broughton, Sidney Peterson, and Willard Maas, who often worked in collaboration with his sometime partner Ben Moore and with his wife, painter and filmmaker Marie Menken. A more occasional experimentalist was Curtis Harrington, who ended up entering the commercial film and television industry. These filmmakers were part of a second wave in avantgarde cinema that revived the energies and styles of the European interwar avant-garde, especially the oneiric atmospheres, the disjointed narratives, the subjectivism, and the corporeal and sexual unruliness that characterized surrealism and that they variously assimilated in accordance with their own interests and personalities. Broughton and Peterson appeared closer to Dadaism-especially in their collaboration The Potted Psalm (1946) - Anger oscillated between extreme subjectivism and mythic reference, Markopou-

11 Dorothy C. Miller and Alfred Barr, Jr., eds. American Realists and Magic Realists (New York: Museum of Modern Art, 1943), 5.

12 Paul Camus, Jared French, Margaret French, Collaboration: The Photographs of Paul Cadmus, Margaret French, and Jared French (Santa Fe: Twelvetrees Press, 1992). For their relation to a larger tradition of homoerotic film and photography, see Tom Waugh, Hard to Imagine: Gay Male Eroticism in Photography and Film from their Beginnings to Stonewall (New York: Columbia University Press, 1997), esp. chapter 2 "Art and Arousal." 
los and Maas tended to lean towards mythic registers, and Deren, who soon disavowed her surrealist affiliation, was more interested in a trans-cultural gestural unconscious than in personal dreams and obsessions.

Postwar filmmakers may have gravitated toward surrealism because it was in vogue in the United States at the time and because the medium of film seemed uniquely capable of blending the real and the unreal. Anaïs Nin, a writer influenced by surrealism and a performer in films by Deren, Anger, and Ian Hugo, noted in a lecture at the University of Chicago that "unconscious life corresponds to film more closely than to any other art."13 The elusive portrayal of the "unconscious life" opened some latitude for the expression of socially proscribed sexual impulses. Under the double cover of the unconscious and of art filmmakers could put their queer lives up on the screen. At the same time, for all their aesthetic debt to their European models, postwar American experimental filmmakers scaled down the production values of interwar surrealism. While Buñuel and Cocteau worked in a professional environment, their American progeny were self-taught amateurs: their cast consisted of friends and spontaneous collaborators without formal training as performers and they used the standard domestic format of $16 \mathrm{~mm}$ film. Their films had the quality of small-scale personal projects, much like poems or paintings.

The unfolding of experimental film in the United States between the early 1940s and the rise of a pop sensibility in the late 1950s is practically coextensive with the reception of European surrealist cinema, or rather, with what in the United States was regarded as such. Its landmarks were taken to be Luis Buñuel's and Salvador Dalí's Un Chien andalou (1928) and Jean Cocteau's Le Sang d'un poète (1930). American filmmakers saw these titles in the early seasons of Amos Vogel's Cinema 16, in New York City, at Frank Stauffacher's Art in Cinema series at the San Francisco Museum of Art, or in cinema clubs and film societies across the country. For P. Adams Sitney, author of the most authoritative account of postwar experimental film to date, American filmmakers took from these predecessors the interest in "the dream state," the depiction of ritual, and the recreation of myth. He traced "dream narratives" and visionary trances to the example of Un Chien andalou, while the interest in ritual and mythology was stimulated by Le Sang d'un poète. ${ }^{14}$ These titles were unlikely to be aligned on the

13 Anaïs Nin, "Poetics of the Film," Film Culture 31 (Winter 1963-64), 12.

14 P. Adams Sitney, Visionary Film: The American Avant-Garde 1943-2000, Third Ed. (New York: Oxford University Press, 2002), 13-15, 28. 
other side of the Atlantic. Openly rejected by the surrealists, Cocteau had originally conceived Le Sang as an anti-surrealist statement. He had tried to avoid "the deliberate manifestations of the unconscious in favour of a kind of half-sleep through which I wandered as though through a labyrinth." 15 However, to most audiences, this half-sleep may not have seemed all that different from the deeper sleep and rampant unconscious of the surrealists, particularly because of the Bretonian virulence of Cocteau's opening intertitles: "With film one can kill death, kill literature, and give life to the poetry of a direct existence." In addition, the similarly hallucinatory quality and fragmentary syntax of these two pre-war masterpieces further contributed to placing them in the same aesthetic category, overriding differences in intention and intellectual allegiance. Charles Henri Ford attested to this perception when, in hindsight, he declared Cocteau "a natural surrealist." 16

While both Chien andalou and Le Sang were crucial predecessors, it was Cocteau's film, and his subsequent work, that exerted the most influence on American filmmakers. ${ }^{17}$ This is corroborated in testimonies by such filmmakers as Maas, Markopoulos, Jerome Hill, Broughton, Anger, Stan Brakhage, or Larry Jordan, among others; they all saw the film in their youth, in the mid-to-late 1940s, and acknowledged its influence. Markopoulos dedicated to Cocteau one of his earliest projects, The Dead Ones (1949) and Maas called Cocteau "the greatest living artist of our time."18 Still, Buñuel-Dalî's Chien andalou had a comparable ascendancy. Sitney regarded it a blueprint for Maya Deren's Meshes of the Afternoon (1943), the title that jump-started the postwar film renaissance and galvanized young West-Coast artists Anger, Markopoulos, and Harrington. ${ }^{19}$ BuñuelDalí and Cocteau also influenced James Broughton and Sidney Peterson,

15 Jean Cocteau, "Preface," Two Screenplays: The Blood of a Poet and The Testament of Orpheus (New York: Marion Boyards, 1985), vi.

16 Ira Cohen, "Interview with Charles Henri Ford," Gay Sunshine Interviews, ed. Winston Leyland (San Francisco: Gay Sunshine Press, 1978), 37.

17 Sitney, Visionary Film, 28.

18 Willard Maas, "Toward the Film Poem," Film Culture 78 (Summer 1994), 11.

19 When Anaïs Nin met Anger and Harrington in the late 1940s, she described them as devotees of Deren and Cocteau. Anaïs Nin, The Diary of Anaïs Nin, 1944-1947, Gunther Stuhlmann, ed. (New York: Harcourt Brace Jovanovich, 1971), 214. Deren's influence was not only aesthetic, important as that was. As Lauren Rabinovitz has shown, she also pioneered styles of distribution and presentation (by renting her films out of her own home, starting small distribution collectives, and introducing them at screenings) that ended up being widely adopted in avant-garde cinema; see Lauren Rabinovitz, Points of Resistance: Women, Power, and Politics in the New York Avant-Garde Cinema, 1943-1971 (Chicago: University of Illinois Press, 1991), 80-85. 
who were additionally indebted to the dada slapstick of René Clair and to Francis Picabia's Entr'Acte (1923), and Willard Maas, whose work combined lyricism and introspection with the revision of classical myth.

Critics have usually regarded postwar surrealist-influenced American films as exponents of subjective cinema. In an influential reading, Sitney classed them as "trance films" and "psychodramas," since they frequently deployed a "first person" narrative, framed as the protagonist's perspective, and were often acted by the filmmakers themselves. In the hands of these directors, "film becomes a process of self-realization" and "inward exploration. ${ }^{20}$ In this way, Sitney aligns them with one of the main thrusts of literary and pictorial modernism: the inward turn towards what Virginia Woolf called "the dark places of psychology." ${ }^{21}$ The central trope in postwar psychodramas, Sitney continues, was "the quest for sexual identity." 22 And considering the number of gay men active in experimental film, this was actually a quest for homosexual - or at least non-straight - identity, more or less veiled yet always readable. This is one of the points of Richard Dyer's important reading of these films: they were largely concerned with "homosexual identity" and "self-disclosure" at a time when "newly assertive gay identities" were being articulated by militant groups and "homophile" societies in various American metropolis - especially New York, Los Angeles, and San Francisco, the main centres of production for quasi-surrealist queer film..$^{23}$ At the same time, Dyer cannily adds, these works problematized the very idea of a homosexual identity, which they subjected to a double process of "construction and dissolution." 24

20 Sitney, Visionary Film, 14.

21 The expression appears in Virginia Woolf, "Modern Fiction," The Common Reader: First Series. Annotated Edition, ed. A. McNeillie (New York: Harcourt Brace and Co, 1984), 152. Classical and influential studies of modernist fiction under the rubric of interiority and subjective exploration are, Robert Humphrey, Stream of Consciousness in the Modern Novel (Berkeley: U of California P, 1954); Eric Kahler, The Inward Turn of Narrative (Princeton: Princeton UP, 1973 [1956]); Melvin J. Friedman, Stream of Consciousness: A Study of Literary Method (New Haven: Yale UP, 1955).

22 Sitney, Visionary Film, 14.

23 Richard Dyer, Now You See It: Studies on Lesbian and Gay Film (New York: Routledge, 1990), 102-104. The standard studies of post-World War II “homophile" activism and subcultural life are John D'Emilio, Sexual Politics, Sexual Communities: The Making of a Homosexual Community in the United States, 1940-1970 (Chicago: University of Chicago Press, 1983) and Lilian Faderman, Odd Girls and Twilight Lovers: A History of Lesbian Life in Twentieth-Century America (New York: Columbia University Press, 1991), 118-158.

24 Dyer, Now You See It, 104. 
While acknowledging the acumen of Sitney's and Dyer's readings, we would like to approach these films from a different premise altogether. Rather than subjective "quests," ruled by the binary possibility of either finding or not finding what one seeks, one might see in these films the tracing of an itinerary or a line across disparate locations. And the goal of linking, through transit, various spaces, may be less the ascertaining of an identity than a material practice - what Michel de Certeau called un art de faire ${ }^{25}$ - that consists in actualizing in unaccustomed ways the spaces of modernity. In this way, we could shift the frame of reference usually applied to these titles from the subjective-"trance," psychodrama-to the objective and material - spaces and their actualisation. From this perspective, the particular surrealism of postwar experimental film would not only be a matter of dreams and symbolic (re)search. It would also have a more practical and materialist dimension: traversing, decoding, and subverting social space - queerly, which is to say, in a manner inflected by heterodox sexuality.

\section{Experimental Film and Queer Psychogeography}

In this regard, postwar film surrealism in the United States brought out a queer component in flanerie, or casual urban drift, a component that, as scholar Dianne Chisholm has pointed out, has been too often erased from the critical reception of this modern trope. ${ }^{26}$ The flâneur, or leisurely stroller, was for Walter Benjamin a paradoxical inhabitant of modernity, at once inside it, as a consumer of city space and its many delights, and outside it, resistant to the fantasmagoric allure of late capitalism. For Benjamin the emblematic modern flâneur had been Charles Baudelaire and the surrealists were his epigons. Chisholm has shown that, while Benjamin and the surrealists were marginally aware of the queer possibilities of flaneire, they did not expound on them. However, in postwar queer film, the flâneur's consumption of urban space is intimately determined by his - seldom her-

25 The term comes from Michel de Certeau, L'Invention du quotidian: Arts de faire (Paris: Union générale d'editions, 1980), translated into English as The Practice of Everyday Life, trans. S. Randall (Berkeley: University of California Press, 1987).

26 In the wake of Janet Wolff's criticism of the masculinist assumptions in the modern flâneur, other theorists have taken issue with this figure's heterosexist biases. See J. Wolff, "The Invisible Flâneuse. Women and the Literature of Modernity," Theory, Culture \& Society 2 (3) (November 1985), 37-46; Sally Munt, "The Lesbian Flâneur," in Mapping Desire: Geographies of Sexuality, D. Bell and G. Valentine, eds. (London: Routledge, 1995), 114-25; and Dianne Chisholm, Queer Constellations: Subcultural Space in the Wake of the City (Minneapolis: University of Minnesota Press, 2005). 
sexual dissidence. Or, in a more telegraphic formulation, we could say that postwar queer film put queer psychogeography on the screen.

The term "psychogeography" was not invented by the surrealists, who nevertheless habitually engaged in its practice, but by the postwar Parisian avant-garde collective of the lettrists, many of whom later founded the Situationist International. ${ }^{27}$ Neither lettrists nor situationists had a direct influence on postwar American experimental film, which emerged nearly a decade before Lettrism made its first appearance, but their ideas on the city, and particularly the concept of "psychogeography," help us clarify the style of urban practice at stake in this cinematic corpus. The concept was first defined in Guy Debord's 1955 "Introduction to a Critique of Urban Geography," published in the Lettrist period. According to Debord, "psychogeography sets for itself the study of the precise laws and specific effects of the geographical environment, whether consciously organized or not, on the emotions and behaviour of individuals." ${ }^{28}$ It explored inchoate but perceptible phenomena such as "the sudden change of ambience in a street within the space of a few metres; the evident division of a city into zones of distinct psychic atmospheres; the path of least resistance that is automatically followed in aimless strolls (and which has no relation to the physical contour of the terrain); the appealing or repelling character of certain places ...."29

One way to experience psychogeographical intimations was through the practice of the dérive-or flânerie: drifting through a particular environment (usually urban) in a state of complete receptiveness to its affective emanations. The dérive was a method of "research for a psychogeographical urbanism." Its finds might help to transform the city from a functional space, planned for circulation or dwelling, to a space of creativity, enjoyment, and adventure. In the words of Dutch painter and architect Constant,

27 Standard accounts of the Lettrist and Situationist International are: Mirella Bandini, L'estetico, il politico. Da Cobra all'Internazionale situazionista 1948-1957 (Ancone: Costa \& Nolan, 1988 [1977]); Greil Marcus, Lipstick Traces: A Secret History of the Twentieth Century (Cambridge: Harvard University Press, 1989); Peter Wollen, "The Situationist International," Rading the Icebox: Essays on Twentieth-Century Culture (Bloomington: Indiana University Press, 1993), 120-58; and Tom McDonough, ed. Guy Debord and the Situationist International: Texts and Documents (Cambridge: MIT Press, 2004). The main documentary compilation is Ken Knabb, ed. and trans. Situationist International Anthology, revised and expanded edition (San Francisco: Bureau of Public Secrets, 2006).

28 Guy Debord, "Introduction to a Critique of Urban Geography," in Knabb, ed. Situationist International Anthology, 8 .

29 Debord, "Introduction to a Critique of Urban Geography," 10. 
who was for a time a member of the situationist group: "We demand adventure ... and we are already attempting to sketch out the image of a happier life, of a unitary urbanism - an urbanism designed for pleasure." ${ }^{30}$

Early situationist writings contain numerous proposals for changing the quotidian experience of the city from rote to adventure: wandering underground in subway stations after the trains have stopped running, slipping at night into houses undergoing demolition, strolling through public gardens at night, or opening the rooftops to pedestrian traffic. ${ }^{31}$ These proposals were spatial versions of détournement: the reworking and recontextualisation of available images, texts, and signs in order to change their meanings. ${ }^{32}$ Space could also be reworked and repurposed with the aim of formulating a "unitary urbanism": a mode of urban dwelling fuelled by desire, fantasy, and play. Unitary urbanism was part of the situationist imperative to revolutionize everyday life, since it was there that the tighter, most complicit, and most elusive forms of repression were exercised.

Lettrists and situationists were explicit about their debt to surrealism. As Ken Knabb has pointed out, their "Proposals for the Rational Improvement of Paris," for example, recalls the surrealists' collective text "Proposals for Irrationally Improving a City," published in Le Surréalisme au service de la révolution in $1933 .{ }^{33}$ The situationists contrasted the original potential of surrealist ideas with the subsequent bankruptcy of the movement, which had become, by the mid-1950s, part of the cultural establishment. Surrealism had succumbed to respectability because it was still too invested in art and aesthetics and had transmitted its proposals through literary and artistic channels, which, by their very nature, blunt the critical potential of the ideas they disseminate. The situationists avoided both. Rather than essays, fiction or poetry, they produced manifestos, articles, position pieces, and political analyses of current events, which they published in obscure, self-produced journals. And rather than conventional art, they practiced détournement the repositioning of previously existing works and images - and produced calculatedly degraded artifacts, such as Gil Wolman's cellotaped collages of

30 Constant, "Another City for Another Life," in Knabb, ed. Situationist International Anthology, 71.

31 "Proposals for Rationally Improving the City of Paris," in Knabb, ed. Situationist International Anthology, 12-13; Debord, "Theory of the Dérive," in Knabb, ed. Situationist International Anthology, 65.

32 Guy Debord and Gil Wolman, "A User's Guide to Detournement," in Knabb, ed. Situationist International Anthology, 20.

33 Knabb, ed. Situationist International Anthology, 479-480n13. 
advertisements, Wolman's and Debord's filmic experiments - some consisting of black leader, with occasional white flashes, accompanied by screams and spoken commentary - or Pinot Gallizio's paintings, a sort of Abstract Expressionism by the yard made in a mechanical manner using industrial paint on uncut canvas and paper rolls. And above all, as Walter Benjamin had done before them, the situationists read surrealism less as an artistic movement than as an attempt to liquidate the category of the aesthetic and to subsume art into everyday life. Consequently, they rejected surrealist art and its focus on subjectivism and interiority and preserved instead its forms of practice, which Debord described as "concrete, collective forms of experimentation with new environments and behaviors," such as those carried out in psychogeographies and dérives. ${ }^{34}$

Both psychogeographies and dérives feature prominently in many of the central works of the movement. Aragon's Le Paysan de Paris and Breton's Nadja (1928), L'Amour fou (1937), and parts of Les Vases communicants (1932), are extended dérives, rich in notations about the emotional radiations of different parts of Paris, from the most picturesque to the most impersonal: boulevards, squares, parks and gardens, gates, bridges, theatres that give the impression of being "at the bottom of a lake," flea markets, the outmoded arcades, or "that great equivocal suburb that rings Paris, the setting for those supremely disconcerting scenes in French serial stories and films in which a special kind of drama takes place." ${ }^{35}$ On these sites took place unexpected coincidences, odd encounters and strange discoveries, such as the objects that Breton came across in the Saint-Ouen flea market, described in Nadja and L'Amour fou. These locations also transmitted unaccountable feelings, such as the sensation of discomfort that the statue of Etienne Dolet on the Place Maubert induces in Breton, the magnetism that prompts him to walk on the boulevard Bonne-Nouvelle drawn by a premonition that an unspecified event will happen there, or the "distinctly murderous atmosphere" that Aragon senses around Buttes Chaumont. ${ }^{36}$

34 Guy Debord, "Contribution to the Debate, 'Is Surrealism Dead or Alive?'," in Guy Debord and the Situationist International, McDonough, ed., 67-68; first published in International Situationiste 2 (December 1958), 32-34.

35 Louis Aragon, Paris Peasant, trans. Simon Watson Taylor (Boston: Exact Change, 1994), 134.

36 André Breton, Nadja, trans. Richard Howard (New York: Grove, 1960), 24, 32; Aragon, Paris Peasant, 133. Margaret Cohen has shown that the affective colour of these places in Nadja is due to the memory of suppressed popular revolts; see Profane Illumination: Walter Benjamin and the Paris of Surrealist Revolution (Berkeley: University of California Press, 1993), 77-119. 
Although the situationists did not prioritise it, sexuality was for the surrealists a powerful psychogeographical stimulus. Much of the fascination that the Passage de l'Opéra held for Aragon stemmed from its sexual possibilities - a hotel used for clandestine assignations, an ambiguous bathhouse, the prostitutes that haunted it at certain times of the day. And the excitement of Aragon's night foray into the Parc des Buttes Chaumont in the company of Breton and Marcel Noll, which takes up the second half of Le Paysan de Paris, owed much to the park's eroticism - to its faux-neoclassical Temple of Love in the highest spot, couples making out in the dark, and the prospect of finding there "a woman" for whose sake "it would at last be worthwhile toppling the universe." ${ }^{37}$ Likewise, the parts of the city that most intrigued Philippe Soupault in Les Dernières nuits de Paris (1928) are quarters where prostitutes ply their trade - like the back streets of the Champs Elysées near the Petit Palais - or where furtive encounters are possible, like the docks on the Seine.$^{38}$ Beyond literature, surrealist film also attests to the erotic suggestions of particular locations. In both Un Chien andalou and L'Age d'or, bourgeois interiors seem to prompt hysterical displays of passion, while in Chien the streets are settings for an impassively flaunted gender bending.

Postwar queer experimental film in the United States continued these explorations of the eroticism of place. Many films in this trend take the form of a transit punctuated by erotic possibility, or in the words of critic and filmmaker Yann Beauvais, of "errancy ... accompanied by sexual availability." ${ }^{39}$ Framed as a dream, Kenneth Anger's Fireworks moves from the protagonist's bedroom to a public lavatory absurdly contiguous to it, where he appears naked on the floor wearing only a sailor cap, on to a bar where he meets a muscle man who flexes his biceps and does handstands for him, and further on to a back alley where seduction turns into aggression and the protagonist is beaten up by a gang of sailors..$^{40}$ After being severely mauled and his chest cut open with a piece of glass, the protagonist reappears unscathed in his bedroom, lying in bed next to another young man whose face has been scratched off the film emulsion in such a way that

37 Aragon, Paris Peasant, 134.

38 Philippe Soupault, Les Derniéres nuits de Paris, préface de C. Leroy (Paris: Gallimard, 1997 [1928]).

39 Yann Beauvais, "Bijoux de famille: L'Influence de Jean Cocteau sur le cinéma experimental," Cocteau, François Nemer, ed. (Paris: Centre Pompidou 2003), 79-82.

40 According to Anger himself, this scene was shot at the men's room in Olive Hill park, Los Angeles, near his home: audio commentary, Fireworks (1947), in The Films of Kenneth Anger, vol. 1 (San Francisco: Fantoma, 2007), DVD. 
it seems to radiate light. The transitions across different settings are abrupt and incongruous, as one might expect from the dream logic that governs the film.

Similar unaccountable transits appear in Markopoulos's The Dead Ones (1949) and Christmas USA (1949), in Maas's Image in the Snow (1948), and in Maas and Moore's Narcissus (1955). Christmas starts out at a fairground, filmed in soft focus, and proceeds in the streets of a quiet neighbourhood, in domestic spaces of uncertain coordinates, a forest and, finally, in an industrial area on the edge of the city. (It was filmed in Toledo, Ohio). In The Dead Ones, two young men meet at the studio of one of them -an artist played by Markopoulos himself with peroxided hair -and they stalk each other through what looks like the Silverlake neighborhood in Los Angeles. There are also glimpses of Chinatown, an unidentifiable run-down shopping street, and Bunker Hill. Image starts with an oneiric sequence on the roof of a building, where a young man sights a number of idealized figures: a crowned woman in a white gown, a male bodybuilder, and a black dancer, each in their own way examples of physical plenitude and grace. He then wakes up in his bedroom in a grimy tenement, which he leaves tempestuously for the grey, littered streets of a "fallen" city. He wanders through the warehouse districts on the Brooklyn waterfront, lingers in rubble-strewn lot where some beggars huddle by a fire, rides the elevated train, catches a peek of a couple making love inside a ground-floor apartment, and ends up at the Woodlawn cemetery, in Queens, in a state of total despair. Narcissus is similarly peripatetic: a ragman in a working-class neighbourhood in Brooklyn scavenges in streets and empty lots, depositing his finds in the cart that he drags behind him. He befriends a street vendor and is insistently solicited by a blonde girl, the sweetheart of the local gang leader, but he flinches at her favours. His routine is interrupted by three dream sequences set respectively on a beach, where Narcissus is romanced by a gaggle of bathing beauties, a "fag bar" - Maas's words ${ }^{41}$ - and a classical pantheon (actually a room at the Metropolitan Museum of Art) where the masked Narcissus appears surrounded by Roman busts.

Even when these films are not framed as dreams, the transitions between their different locations have a dream-like vagueness and syncopation.

41 Willard Maas, “The Gryphon Yaks," Film Culture 29 (1963), 49. On the queerness of Maas's films see Juan A. Suárez, "Myth, Matter, Queerness: The Films of Willard Maas, Marie Menken, and the Gryphon Group, 1943-1969," Grey Room 36 (Summer 2009), 58-87. 
Rather than conventional narrative spaces subordinated to the axes of action and causality, the films present locations pervaded by powerful affective latencies. Movement between different milieus, and between dream and reality, is motivated by the pull of desire. The "real-life" solicitations on the shy Narcissus are continued in the dream scenes; and the photographs that the protagonist of Fireworks has been contemplating in his waking hours - seen on the floor of his bedroom-become dramatized in his dream. In Anger's, Harrington's, and Markopoulos's films, characters pursue the objects of their desires, while in Maas's they recoil from them. Following their desires, or recoiling from them, the itineraries of the films' protagonists string together private and public, or semi-public, locations in which streets and bars abound.

The films show a definite predilection for spaces of circulation and transit. One of the earliest shots in Markopoulos's The Dead Ones pans down the façade of Los Angeles's railway station and ends up resting on an ornamental detail on the sidewalk, and much of the film unfolds in streets, alleyways, intersections, and public squares. Fireworks contains two quick frames of night traffic - on Los Angeles' Cahuenga pass - that momentarily interrupt the succession of medium and medium-long shots of human figures. ${ }^{42}$ These quick, slightly incongruous takes might be regarded as a way to further disorientation or as a visual pun on "cruising" - both moving and seeking for casual sex. And the climax of Christmas USA, an elusive scene that could depict a sexual encounter, a ritual, or a moment of selfacceptance, takes place in an empty lot under a bridge by the railroad tracks while a moving train is visible in the back of the frame.

Spaces of circulation, usually governed by functionalism, utility, and speed, are transformed in these films into landscapes of erotic daydreaming and possibility. The emphasis on movement suggests the nomadic nature of desire, an inexhaustible centrifugal force, and also evokes the erotic undertones of motion - especially urban motion - and its associated spaces, such as avenues, train and bus stations, and traffic hubs. These are spaces for temporary occupation: borrowed, rather than properly inhabited, they lack personal marks, and are pregnant with the possibility, new in modernity, of a floating desire that frequently changes object. These sites allow desire to

42 Ara Osterweil points out the location of these shots. Ara Osterweil, "Close Up: America Year Zero," Artforum 55 (5) (2017). https://www.artforum.com/print/201701/ara-osterweil-on-kenneth-anger-s-fireworks-1947-65390; last access, November 22, 2018. 
become depersonalized and disconnected from habit and continuity. As they elude familial or informal social supervision, they foster sexual adventure. In fact, there seems to be a narrow connection in modernity between transit and sexual transgression, a connection that these films insistently bring up. They seem to confirm Swedish anthropologist Henning Bech's insight that stations, streets, and squares condense the erotic possibilities of the metropolis because of the endless moving crowds and the virtually unlimited availability of faces and bodies for contemplation and even ephemeral connection..$^{43}$ These films also anticipate later work - not in a surrealist vein - that emphasises the association between movement and unconventional sexuality, like Frank Ripploh's Taxi zum Klo (1980) or, in a different mode and medium, Del LaGrace Volcano's 1990s photo series Nymphocabbie, on lesbian and trans- cruising in the London parks.

In any case, sexuality is an ever-present possibility both in public and in private. These films attenuate the difference between both realms as they project onto public locations what had traditionally remained private. While desire starts in intimate recesses, it is often pursued in the open, where it might be consummated as well. It almost happens in Fireworks, but then the aggression occurs, which might be read as both interruption and sexual fulfilment, however. Some consummation seems to take place in Christmas $U S A$, where the long-delayed encounter of the two protagonists also takes place in an open space. This way of privatising public space may be one of the most radical proposals in these films, which carry out the surrealist eroticization of the city and the situationist desire to infuse collective spaces with adventure - even if homosexual cruising was not exactly the kind of adventure that either surrealists or situationists had in mind.

Queers in the pre- and postwar years did have cruising very much in mind, and turned public locations into settings for the pursuit of sex, thus appropriating collective urban locations for intimate use. As George Chauncey has stated in his groundbreaking work on New York gay male life in the early twentieth century, "privacy could only be found in public." ${ }^{44}$ It was often easy to escape supervision in the anonymity of big cities and to find

43 Henning Bech, When Men Meet: Homosexuality and Modernity (Cambridge: Polity Press, 1997).

44 George Chauncey, Gay New York: Gender, Urban Culture, and the Making of the Gay Male World, 18901940 (New York: Basic Books, 1994), esp. 179-205. 
clandestine pleasures in neglected corners of the urban fabric - parks and industrial areas after dark, certain streets at certain times. Just as Chauncey did for New York, Stuart Timmons, Lilian Faderman, and Nan Alamilla Boyd have documented that, at least since the beginning of the twentieth century, Los Angeles and San Francisco had intricate queer scenes that included bars and dance halls, private party networks, and extensive cruising sites. Some were relatively brazen, as was the case in the 1940s and 1950s with Los Angeles's Pershing Square or Griffith Park, or with certain parts of New York's Greenwich Village or Times Square; others were hard to identify by the unsuspecting. In their poetic manner, postwar queer experimental films allude to the erotic charge that public space often held for queers, and to the way in which what had conventionally been regarded as private could be played out in the open - with a measure of caution. A similar desire to privatize public space and to publicize the private impelled numerous gays, lesbians, and transvestites in the war and postwar years to photograph their parties, sexual encounters, cruising spots, beach outings, and park rambles, as well as boyfriends, girlfriends, friends, casual trysts, and even figures glimpsed at a distance and furtively captured. Many of these images - Indiana University's Kinsey Institute probably has the largest repository of them - were meant for private consumption but they still contain a record of the numerous arousals of public space..$^{45}$

The Kinsey Institute collections show that "sexing" and queering the city were clearly exhilarating for many, who did it with humor and flair. However, public eroticism in postwar queer cinema is invariably elegiac and closely connected with violence and aggression. The protagonists of both Fireworks and Narcissus are objects of gang violence. In Fireworks, violence may be read as a response to the main character's sexual interest in another man, boldly displayed at a bar. Yet it also echoes, as Ara Osterweil has shown, the aggressions that Los Angeles pachucos suffered during the zoot suit riots of 1943, and therefore hints at the protagonist's crossracial identification with Mexican-American youth. ${ }^{46}$ In Narcissus, violence

45 Research of the Kinsey Institute's Photographic Collection took place on November 15 to 19, 2010. Our thanks to the Institute's staff for their help.

46 Ara Osterweil, "Close-Up: America, Year Zero.” Anger spoke of his experience of the zoot suit riots in interview to Matthew Hays, "Kenneth Anger, Director: Fireworks at Sixty" The Gay and Lesbian Review (March-April 2007); available at: https://glreview.org/article/kenneth-anger-director-fireworks-at-sixty/ ; last accessed November 22, 2018. Bill Landis claims that the film has an autobiographical origin: Anger was entrapped by police at Palisades Park, Bill Landis, Anger: The Unauthorized Biography of Kenneth 
breaks out in retaliation after the protagonist slaps the girlfriend of a tough youth in order to stall her advances; misogynistic aggression and auto-erotic self-absorption, rather than the libidinal display of Fireworks, trigger the violent response. The central character in Image parades his anguish and guilt through the city, and agonizes at the end of the film in a cemetery in the middle of a raging snowstorm.

In Curtis Harrington's Fragment of Seeking, eroticism also conjures the spectre of death. The timorous young protagonist (Harrington himself) pursues a young woman whom he spots sitting at a table outdoors in the company of a good-looking, athletic man. She is enticing and elusive, framed by windows and doors, and viewed across courtyards and at the end of dimly lit hallways. When he finally catches up with her, in a scene bracketed as a dream, she turns into a skeleton in his arms, while her attractive escort is briefly shown slumped on the table he had been sharing with her, apparently dead. Subsequently, the woman and the protagonist seem to fuse. The latter appears in women's clothes and in a blonde wig that imitates her hair, and eventually takes her place in the company of her partner while she becomes the outside observer and stares at them from the roof of a nearby building. It is as if the ultimate objective of the protagonist was not her, as it appears at the outset of the film, but her place as partner of the athletic youth, and she was merely the temporary occupant of this position, the fulcrum on which hinges the men's homoerotic link. Yet to take her place, the timorous youth and the woman have to die symbolically: she becomes a skeleton in his dream and, undergoing a change of gender, he becomes her double, at which point he takes her position at the table, and the film returns to the opening scenario.

The connection between publicly demonstrated desire and aggression might have been prompted by the contemporary repression of homosexuality, which was particularly virulent in the late 1940s and early 1950s, the high years of McCarthyism. But the close association of sexuality and death is also an integral part of surrealism's imaginary, where desire is frequently the catalyst of physical and emotional undoing. This is the case as well in queer-inflected American surrealism. Relationships in Ford and Tyler's The Young and Evil and in Djuna Barnes's similarly queer (and surreal) Nightwood (1936) are rife with betrayal and abuse. In addition, The Young and 
Evil underlines the ambiguity of public spaces as both erotic and dangerous. In a late chapter ('Cruise'), a walk on New York's Riverside Drive, a well-known cruising ground at the time, turns into a scene of mob violence, when a number of sailors chase and beat up protagonists Karel and Frederick, obvious queens on the prowl. Melancholia tinges Lynes's and Pajama's photographs: their highly stylized, uncertain spaces - whether natural, in Pajama's case, or studio-bound, in Lynes's case - are settings for elliptical scenarios of isolation and loss featuring solitary males or groups in which bodily proximity seems devoid of reciprocity and warmth.

The mixture of eroticism and violence, moody high-contrast lighting, and frequent black and white photography bring postwar queer surrealist film into the orbit of film noir. Noir also deployed the spaces of urban modernity as stages for stories that tarried with the perilous undertow of sex and desire. As Richard Dyer has shown, the epistemic uncertainty of its plots communicated to many of the characters a measure of sexual undecidability. ${ }^{47}$ In many ways, film noir offers a psychogeographical exploration of modern metropolitan life. In Thomas McDonough's view, this must have been present to Guy Debord when he titled a psychogeographical map of Paris composed in 1957 Naked City, after Marvin Wald's 1948 homonymous film noir. ${ }^{48}$ And there are numerous continuities between film noir's menacing cityscapes and the enigmatic atmospheres of such surrealist mainstays as Brassaï's photographic series "Paris by night," Soupault's Les Derniéres nuits de Paris, Aragon's Paysan de Paris, and Breton's Nadja. Even if American queer filmmakers and photographers were not fully aware of these parallels, which belong to film noir's unconscious, they may have been drawn to the stylish atmosphere and experimental traits of film noir, this cycle, to noir's doomed view of eroticism, and to its way of rendering unfamiliar contemporary city space.

Alongside eroticism, myth played a crucial psychogeographical role in postwar experimental film. In Aragon's provocative formulation, myth was the passage through which the reality inapprehensible by consciousness or the senses manifests itself. He called this reality "nature"-_the limit of my mind" - and made it co-extensive with the unconscious. It was not a personal, individual unconscious, but, closer to Gilles Deleuze and Felix

\footnotetext{
47 See Richard Dyer, "Homosexuality and Film Noir," Jump Cut 16 (1977), 18-21; and, a more exhaustive treatment, R. Dyer, "Queer Noir," The Culture of Queers (London: Routledge, 2002), 90-114.

48 Thomas F. McDonough, "Situationist Space," October 67 (Winter 1994), 59-77.
} 
Guattari's conception, ${ }^{49}$ a material, supra-individual realm of connections that Aragon imagined at times as "a machine": a "large wheel which is spinning and which is no longer steered by a hand." ${ }^{50}$ Myth is the conduit for this bond - the channel that transposes unconscious energies and affects to consciousness, and Le Paysan de Paris, where these formulations are found, along with much other surrealist writing, was an attempt to forge a modern mythology. Postwar queer experimental film further contributed to modern mythology along surrealist lines. By means of psychogeographical research and the sexualization of public space, it pursued the obscure latencies of "nature" in the city, while it also emphasized, to a larger extent than Aragon did, the fact that heterodox sexuality was a substantial component in "nature" and, therefore, in the mythic perceptions that channelled it. Except that in American experimental film, myth remained, to a great extent, tied to ancient Greco-Roman figures-stand-ins for impulses that were denied presence and agency in modernity but remained operative as icons of desire.

The mythic substratum is most evident in Maas and Moore's Narcissus (1955), in Charles Henri Ford's Johnny Minotaur (1971), and in most of Markopoulos's oeuvre - his early trilogy, De la sang, de la volupté et de la mort (1947-49) and Twice a Man (1964) are representative examples. These titles offer modern versions of ancient myths. Some are rendered in contemporary guise: in Maas and Moore's film, Narcissus is a contemporary rag-and-bone man; in Ford's, the Minotaur is recreated by modern beachgoing Cretan adolescents in papier mache masks, who are revered by a fascinated gaggle of international tourists; and in Markopoulos's early trilogy, mythological characters alternate between ancient and modern settings and garments. Other films refrain from citing concrete myths and only present ritualized behaviour. In one of the final scenes of Fireworks, the protagonist triumphantly carries on his head a Christmas tree hung with tinsel, perhaps a way to signify the assumption of his sexual cravings, symbolized both by the tree adornment and by the fire in the hearth. The protagonist of Christmas USA improvises an altar in the middle of the forest, possibly in an attempt to invoke his younger partner (or is it his counterpart?), whom he effectively meets later on in the film. And the distraught hero of Image

49 The fullest exposition of this "machinic unconscious" is Gilles Deleuze and Felix Guattari, The AntiOedipus, trans. R. Hurley, M. Seem, H. Lane, vol. 1 of Capitalism and Schizophrenia, vol. 1. (University of Minnesota Press, 1983).

50 Aragon, Paris Peasant, 123-24. 
dreams up figures who have mythic resonances without belonging to any particular mythological system. These figures are considerably homoerotic, especially the muscle man who vanishes when the protagonist tries to touch him, and the black dancer - a modern Orpheus? - first glimpsed at the bottom of a light shaft and later seen descending a rope ladder, as the roof seems to transmute into a boat deck. In all these instances, myth and ritual reenchant everyday spaces by conjuring up transhistorical icons and forces in their midst. The effect is stronger the more identifiable and proximate the setting, as is the case with the slum inhabited by Maas and Moore's Narcissus, or the prosaic rooftop on which the youth in Image encounters his private pantheon.

Mythic reference invests customary banality with transcendence, ordinariness with timelessness and uniqueness. In Markopoulos's Psyche (1947), the first film in the trilogy De la sang ... streets, parks, and beaches around Los Angeles become the settings for an idiosyncratic version of the ancient story: Psyche attempts to escape the tainting desires of slightly predatory males - the influence of Eros - to relish her loneliness and, perhaps, cultivate her own lesbian longings. ${ }^{51}$ Similarly, present-day New York and Staten Island become, in Markopoulos's Twice a Man, the backdrop of Hippolytus's second life after he is revived by Aschlepius, who then becomes his lover. The Staten Island Ferry, skyscrapers, alleyways, and rooftops acquire a new depth as they become permeated by the classical plot. The oscillation between the contemporary and the ageless in these examples is structurally similar to the split between lawfulness and lawlessness, ordinary and extraordinary that characterized queer subjects at the time, many of whom had to pass for "normal" in their daily lives while their sexual practice and behaviour often distanced them from normality. This duality makes space ghostly and spectral, haunted by the sense that there is always something else than what is immediately present to the naked eye - a realm of otherness that may spring up any moment. In fact, these films narrate the more or less traumatic eruption of such otherness, offering in this way queer versions of the Freudian uncanny. Experiences that were once familiar (the wayward sexuality of classical myth and the outlawed sexuality of contemporary subjects) return in unaccustomed form after be-

51 Markopoulos claimed that Pierre Loüys's unfinished novella Psyche was the inspiration for the film. Gregory Markopoulos, "Psyche and the Search for the Herb of Invulnerability," (1955) Film as Film: The Writings of Gregory Markopoulos, Mark Webber, ed. (London: Visible Press, 2015), 178-81. 
ing rendered strange through repression and the threat of punishment..$^{52}$

Dreams and visionary passages express this duplicity; they show the division of experience into two distinct yet connected levels (real and ideal; factuality and dream) and the division of the protagonists within themselves. To an extent, this duplicity harks back to the structure of gothic fiction - an influence on Harrington's Fragment and on Deren's Meshes of the Afternoon, and, to a lesser extent, on Anger and Markopoulos. In gothic narratives doubles, spectres, and doppelgangers abound; according to Eve Sedgwick, they may be read as covert expressions of same-sex eroticism that, turned strange and hostile, may then be disavowed as undesirable. ${ }^{53}$ In this body of film, however, the ghostly double of homoerotic desire is embraced as a qualified possibility - qualified because of the dangers attendant on such embrace at the time. The emphasis on duplicity may be why Narcissus is insistently revisited in this film cycle. The Narcissus story adds to the duality of mythic allusion a further doubling: of the protagonist and his reflection, tied in a solipsistic feedback loop. Such doubling is a strategy to escape heterosexuality and normalization, even if in this refusal there is an ingredient of misogyny that represents women as bearers of death - a nagging blind spot in several of these titles. The Narcissus motif places en abyme the internal splitting that characterises these films' plots, their implicit conceptions of subjectivity, and their disjunctive discursive style. Splitting also characterizes these works' social circulation and intellectual genealogy: they are European in lineage but American in setting and implication; narrative but also tonal and poetic; experimental and popular; surreal and queer.

\section{Into the Post-city}

And to add one more duality, these films are posed between two moments

52 I am alluding here to the classic Freudian formulation of the uncanny: Sigmund Freud, "The "Uncanny" (1919), in The Standard Edition of the Complete Psychological Works of Sigmund Freud, ed. \& trans. James Strachey, vol. 17 (London: Hogarth, 1953), 219-252. Hal Foster has made the Freudian uncanny central to surrealist aesthetics; see in particular his reading of a spatial uncanny where repressed modes of capitalist production and relation return: "Outmoded Spaces," Convulsive Beauty (Cambridge: MIT Press, 1995), 157-93.

53 Eve Kosofsky Sedgwick, Between Men: English Literature and Male Homosocial Desire (New York: Columbia University Press, 1985), 83-96 
in urban evolution: between what Edward Dimendberg has called the "centripetal" modern city (the dense, walkable city of the early twentieth century) and the "centrifugal" post-city of suburbs, malls and specialized land use that began to develop in the late $1950 \mathrm{~s} .{ }^{54}$ In the new city sprawl, concentration gave way to dispersal and walking to driving, which diminished the chances for disconcerting finds and surprising encounters. Furthermore, urban dispersion attenuated the influence of the built environment on eroticism or, what is the same, the psychogeographical valence of the city, since contact with the terrain became mediated through moving vehicles. Tactile activation of the environment - through personalized trajectories, individual rhythms of walking and pausing, motion and contemplation - was replaced by visual consumption at a distance; and the free itineraries of the body, by regulated thoroughfares.

The post-metropolis is not yet visible in postwar queer films but, in hindsight, it seems to haunt them. In many ways, the queer dérives they portray could only happen on foot: the tentative pursuit of the blond artist by the dark youth in The Dead Ones; the disorienting passage from private to public locations and back in Fireworks, Psyche, and Twice a Man; the tortured drift of the protagonists of Fragment of Seeking and Image in the Snow; Narcissus's meticulous scavenging: all were predicated on the ability to walk the city, in close contact with its orography and tectonics. The transition to a new urban layout is visible on a few occasions. Shots of night traffic in Fireworks foreshadow future car-centred Los Angeles, a premonition corroborated by the final sequence in The Dead Ones, when the dark youth digs a grave for his deceased friend under a highway bridge under construction. And the mountains of rubble that punctuate the slums in Narcissus and the waterfront in Image index the ongoing liquidation of the inner city.

Along with the traditional city was liquidated a way of relating to it. The new dispersed environment erased a style of spatial practice that started around the times of romanticism as a response to the industrialized environment and that was chronicled, among others, by Edgar Allan Poe, Lautréamont, Gerard de Nerval, or Charles Baudelaire. All of them reported the experience of drifting through a city in complete openness to what Aragon called its "natural" life - its unconscious. Surrealism, which Benjamin once

54 Edward Dimendberg, Film Noir and the Spaces of Modernity (Cambridge: Harvard University Press, 2004). The standard history of this development is Kenneth T. Jackson, The Crabgrass Frontier: The Suburbanization of America (New York: Oxford University Press, 1985). 
described as "a new art of strolling," ${ }_{55}$ was one more chapter in this manner of inhabiting the modern city. This "art of strolling" resulted not only from applying a particular cast of mind (disponibilité; psychogeography) to the environment. It also depended on the porosity and permeability of the contemporary urban fabric: a multi-layered, heterogeneous terrain where attempts at order and regularity were invariably undermined from beneath through hallucinated transit and wayward use. Queer spatial practice cruising, turning public locations into settings for intimacy and sexuality was one of these wayward uses. It converged with surrealism in this body of films, which, under close examination, turn out to be as much about urban practice as about identity or aesthetics. Subjective and visually striking, but also objective, materialist, and situated, they are essays on introspection and arresting stylistic exercises, but also inquiries on the erotic possibilities of the modern city. 